\title{
About the Possibilities of the Stratigraphic Analysis for the Chronological Attribution of the Rock Art Monuments (on the Example of the Tepsei Petroglyphs)
}

\author{
Irina V. Abolonkova and Maria A.Taliagina* \\ Kemerovo State University \\ 6 Kemerovo, Krasnaya Str., 650043, Russian
}

Received 31.10.2014, received in revised form 14.03.2015, accepted 31.03.2015

\begin{abstract}
The article is devoted to the stratigraphic analysis of petroglyphs at one of the planes with numerous palimpsests of the rock art monument, Mount Tepsei. It contains zoomorphic and anthropomorphic figures performed using the engraving technique. Nowadays there are a lot of opinions regarding the dates of these or those images of this plane. The implementation of the stratigraphic method has given an opportunity to follow the sequence of engraving the images on the plane, additional methods allowed to determine a certain chronology. As the result of the analysis the following chronological frames of creating the petroglyphs have been determined: from the New Stone Age (?) to the Ethnographic Time. Generally, the results obtained can be used for dating similar images both for Tepsei and other rock art monuments of the adjacent territories.
\end{abstract}

Keywords: Tepsei archeological complex, Tepsei II, petroglyph, stratigraphic method, palimpsest.

Research area: history.

Each plane of the rock art monument is like a page of a book, when the meaning of the whole art piece gets lost without reading this one page. The Tepsei archeological complex is a kind of a "multi-volume edition of petroglyphs", the images of which are observed at the rock outcrops of Mount Tepsei (Points: 1-5 (Sher, 1980: 147; Sovetova, 1987: 173-176; Blednova et al., 1995: 32)). The overall picture of the art sources of the monument is supplemented by the petroglyphs located at numerous mound stones below the mount (Savinov, 1976: 57-72; Nikolaeva, 1983: 10; Bokovenko, 1987: Fig. 2: 3; Miklashevich,
2013: Fig. 2: 2; Abolonkova, Taliagina, 2014: 113-116 et al.). The images were engraved on the rocks at different time, and often ancient and medieval artists had been choosing the same planes for their drawings. Often new images were put over the old one or "imrinted" into the free space complicating the composition or absolutely distructing its meaning. In addition to the aesthetic component, such cases of so-called palimpsests are of great interest to researchers, while the stratigraphic method of petroglyphs dating gives some opportunities for chronological attribution of the monument as a whole. The method consists

(C) Siberian Federal University. All rights reserved

* Corresponding author E-mail address: abolonirina@mail.ru, talyagina.maria@yandex.ru 
in establishing a relative chronology of images, by examining the overprinting of rock carvings on each other. This method can specify which figure was applied earlier. However, to answer the question of the time of images creation, it is necessary to involve other dating methods (e.g. stylistic analysis).

Stratigraphic analysis of one of the planes of Tepsei II in conjunction with other methods of rock art dating can solve some of the problems with the chronology of the series of the monument's petroglyphs, as well as to get closer to the ideas of the ancient artists in a way and imagine how the stone pages of the Tepsei mountain range were filled in with drawings.

Let us consider one of the planes (Fig. 1) as an example. Its location and size, obviously, has resulted in its appeal for the population living there for several epochs, which is confirmed by the presence of numerous palimpsests. Multitemporal images are located on a massive rocky outcrop of the Devonian sandstone ( $2 \times 1.5 \mathrm{~m})$, facing southeast in the mouth of Volchy ravine (in the first ridge of Tepsei II). Due to the protruding upper part of the block forming a small peak above the bottom part, the plane is visually divided into two parts: the upper and the lower. The size of the images and techniques used for making them confirm that the images were made at different times.

For more than a century of studying the petroglyphs of the Tepsei archaeological complex (Spassky, 1857: 145; Adrianov 1904: 28; Sher, 1980: 146-148; Bokovenko, Leontiev,

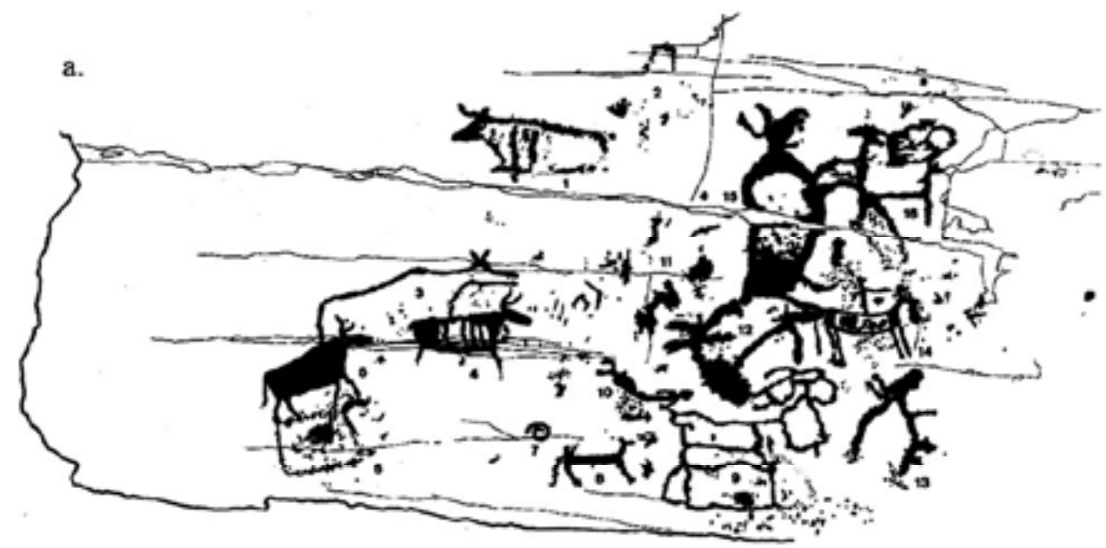

6.

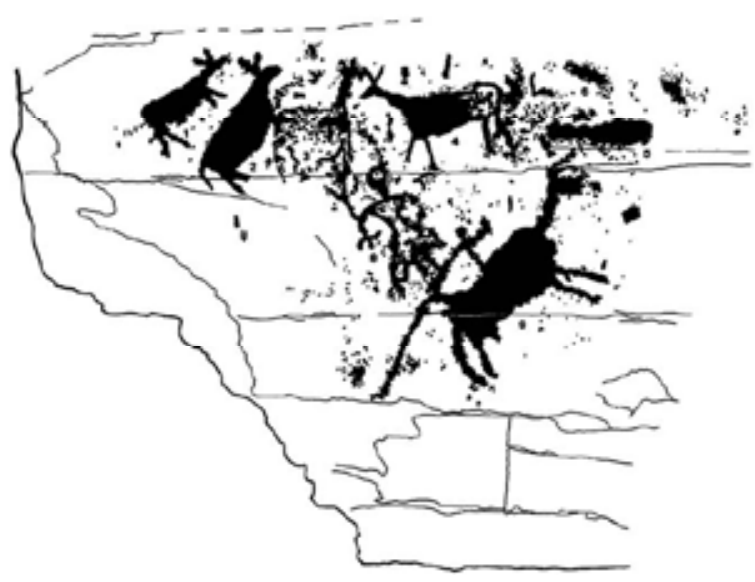

Fig. 1. (according to Francfor, Sacchi,1993) 
1985: 192; Sovetova, 1995: 33-54; Blednova et al ., 1995; Pankova, 2004: 52-60; Cave art of the Middle Enisey, 2007: 118-121; Sovetova, Mukhareva, Abolonkova, 2012: 77-90 et al.), continuous research interest in this block with images contributed to the formation of a variety of opinions among scholars regarding dating of its images, most of them have a number of similarities with the petroglyphs of both Tepsei and other monuments of rock art of the Minusinsk Hollow.

For the first time the drawings of this plane were published in Ia.A. Sher's work (1980: Fig. 71), but the author did not provide dating of the images due to the multitude of tasks reflected in the monograph. The monograph includes the results of the years-long work of the Kamensk team of the Krasnoyarsk Archeological Expedition, which the researcher had been supervising in 1960-70s. In general, with respect to the petroglyphs of Tepsei II, Ia.A. Cher wrote that most of the faces with images were located at the first and third levels from the bottom, "there are little expressive images, dating is uncertain." (Ibid: 148).

The first attempts of chronological interpretation of the plane's images being analyzed were taken by O.S. Sovetova basing on the results of the work performed by the Petroglyphic team of Kemerovo State University (1983-1984), who copied the drawings in the ravine at Mount Tepsei, including those, which were at a considerable distance from the bank of the river and were not copied by the Kamensk team. O.S. Sovetova writes that the earliest drawings of Tepsei II are located on the plane we are interested in: there are images from the Bronze Age (bulls), and, perhaps, from earlier times (an elk in the upper part of the plane), and the Tagar (an animal with a rider etc.) and the Tashtyk Ages (a human) (Sovetova, 1995: 34).
Specialists from Krasnoyarsk, exploring the complex in the 1990s, also paid attention to the drawings of this plane. The figures of bulls and deer were dated by the Copper Age; images of people, riders and certain animals made schematically were dated by the early Iron Age; vague figures and symbols by the Medieval Age (Cave art of the Middle Enisey, 2007: 120).

A more detailed analysis of the images of this block is reflected in the work by French specialists, who visited Tepsei I and II in cooperation with Russian specialists (from Kemerovo State University) in 1992 (Francfor, Sacchi, 1993: 3033). Nevertheless, the chronological interpretation in their publication is not fully reflected, and some conclusions are doubtful, for example, dating of the images in the bottom part of the plane by the Tashtyk Age (Ibid: 33).

The images in the bottom part of the block were also published in the work by O.V. Kovaleva, who dated them by the Bronze Age (2011: Table 51).

The detailed analysis of the images of this plane with implementation of the stratigraphic method allowed to determine the following chronological layers of the petroglyphs.

It appears that the earliest image is the image of an elk (Fig. 3) located in the upper part of the plane and covered by the figures of bulls (Fig. 4, 5). The stylistic peculiarities of this image (a small head with a neb stretched forward, schematism combined with realism etc.) allow to refer it to the art traditions of the Minusinsk style, the problem of dating which has not been completely resolved yet. Such images never overlap other images, at the same time being often overlapped by later images, which allows to refer them to earliest petroglyphs. Some researchers do not exclude the possibility of their Upper Paleolithic Age (Sher, 1980: 193; Piatkin, Martynov, 1985: 138; Sovetova, Miklashevich, 1999: 53-55), others date the images made in the 
Minusinsk style by the Copper Age (Podol'sky, 1973: 271, 275; Rusakova, 2005: 215; Esin, 2010: 53-73). It is noteworthy, that the figure we are referring to surprisingly reminds of the image of an elk on the Tuba part of Tepsei (Ust-Tuba) dated by Ia.A. Sher by the Neolithic Age (1980: Table 1:4). We cannot ignore the possibility that these images may belong to one and the same ancient master. Such cases are often observed on the rock art monuments. It is well known, that the petroglyphs of the Minusinsk style almost always tend to be located near water. On Tepsei such images can be found on the planes facing the Yenisei, in Tepsei I (Blednova et al., 1995: pl. 1-9). A partial image of an animal combined with a boat was found on the rock block near Tepsei II (near "the cross") in 2013. The image was made in the similar style. The early figure of an elk on the plane we are interested in, which is not facing water, obviously proves its special meaning for the ancient.

The bulls overlapping this image were made later and more likely belong to the Bronze Age, similar to the figures of bulls of UstTuba (Sovetova, 1995: 34). Such images are distinguished by the position of legs, inclination of the head, the expressive hump on the back, lines crossing the body of the animal. The problem of their dating has not been completely resolved yet (Kubarev, 2011: 25; et al.). The French researchers point out the figures (and the images 1, 6, 13, 15) refer to the Bronze Age, but they also date the figure of the elk overlapped by the bulls by the same time period (Francfor, Sacchi, 1993: 33). O.S. Sovetova supposes that this composition belongs to the stylistic group of bulls constantly appearing along with the image of the elk outlined by Ia.A. Sher (Sovetova, 1995: 34).

Two images of uncertain animals with their heads up (Fig. 13 and 15) are especially interesting, while next to the plane under a layer of moss a figure, stylistically reminding of similar images, was found. Analysis of palimpsests has shown that one of the figures is overlapped by the later image of a rider (Fig. 14), dated by the Tesin Age, while it is made in its typical art tradition ("degeneration of the Scythian-Siberian style" according to Ia.A. Sher) (1980: 251). Dating of figures 13 and 15 is quite complicated, but thanks to the palimpsest the chronological framework during which these images could have been created becomes more clear. The French researchers referred them to the Bronze Age (Francfor, Sacchi, 1993: 33). Let us note that we also met with figures of bulls among the Tepsei images with their heads up (such cases are also known according to other petroglyphs) as figure 13, and if we can assume that it belongs to the Bronze Age, then figure 15 is more complicated. This image has features both typical for an elk and a bull (there is a similar image on the southern slope of Tepsei). According to Iu.N. Esin, such animals demonstrate the effect of ritual and mythological ideas of alien herdsmen on the world views and the traditions of fine arts of local hunters and fishermen (Esin, 2010a: 83). However, bulky appearance and a lack of skill in performance suggest that this image can be a later replication.

Returning to the figure of the rider (figure 14) stylistically performed in the Tesinsky style where the body of the figure is filled with curved lines and swirls, becoming purely formal, we note that figure 9 apparently relates to the Tesinsky Age. Due to D.G. Savinov's discovery of stone tiles with similar images of spirals, circles, labyrinths and abstract motifs in the Tesinsky burial Esino III, it has become possible to refer a whole series of images to this period (2009: 89-90). Presumably, figure 7 also refers to this time period. This assumption does not coincide with dating of the French colleagues who refer the figure of the rider to the Iron Age, as well as figure 8 , and accept their possible creation during the Tashtyk Age, but without any evidence. We 
believe that figure 6 , partially overlapping the image of the bull (figure 5) also relates to the Tesinsky epoch.

Researchers argue about dating of the images located on the lower block (Fig. 1b): they are dated by the Late Bronze Age (Kovaleva, 2011: Table 51) and the Tashtyk Age (Francfor, Sacchi, 1993: 33). It is noteworthy that the specifics of the stone itself, which was probably exposed to bundling at some time, suggests possible later replications made by artists to imitate the ancient samples.

Figures 1, 2, and possibly 4 refer, in our opinion, to the same chronological layer. Figures 1 and 2 are stylistically similar: 4 legs, a stout body, a small head with small disproportionate ears placed apart. Figure 4 is close to the above mentioned images due to a massive body and ears placed apart, and also due to the extent of patination and the nature of imprinting: fine pointed; the bodies of the animals are carefully designed. Figures 2 and 4 are overlapped by the image, which stylistically reminds of the Tashtyk drawings, which indicates the earlier time of creating figures 1, 2 and 4 . The image of a man in the central part of the plane (figure 8) also displays a number of similarities in the Tashtyk art (Sovetova, Miklashevich, 1999: Table 6). The type of imprinting also brings together figures 3 and 8 . The above mentioned anthropomorphic character is overlapped by the roughly imprinted image of a rider, which was obviously created in the Ethnographic time.

Therefore, the stratigraphic analysis of the images using stylistic interpretation allowed to correlate the petroglyphs with different chronological time periods they are likely to have been created during: from the Neolithic (?) to the Ethnographic time. By identifying numerous cases of overlapping one images by some others, it can be assumed that this plane had been playing a special sacred role for the ancient population of the province for many eras. Moreover, we should not ignore the fact that there are no such other planes with palimpsests on Tepsei, therefore, the analysis performed gives a sort of a key to dating of many images printed on the rocks at various points of Tespei, and is also important for the chronological attribution of petroglyphs of the Minusinsk Hollow as a whole. Finally, using one plane and putting new figures, on the one hand, was an obvious "negation of negation", but on the other hand, may be they were enriching the story, adapting it to their worldviews. The proximity of the stone block to the mound field suggests that the petroglyphs were probably involved in the ritual sphere for a long period of time.

\section{References}

1. Abolonkova I.V., Talyagina M.A. K voprosu okhrany i ispol'zovaniia kurgannykh kamnei s risunkami pod goroi Tepsei [On the Issue of Protection And Use of Mound Stones With Drawings Under Mount Tepsei] // Drevnie kul'tury Mongolii i Baikal'skoi Sibiri [Ancient Cultures of Mongolia and the Baikal Siberia]: the V International Scientific Conference: 2 p. Kyzyl: Tuva State University, 2014. Part 2. Pp. 113-116.

2. Andrianov A.V. Predvaritel'nye svedeniia o sobiranii pisanits v Minusinskom krae letom 1904 g. [Preliminary Information on the Collection of Petroglyphs in the Minusinsk Region in the Summer of 1904] // News of the Russian Community. For the Study of Central and Eastern Asia. SaintPetersburg, 1904. Issue 4. Pp. 25-33.

3. Blednova N., Blednova N., Francfort H.-P., Legchilo N. et al. Repertoire des Pétroglyphes d'Asie Centrale, Fascicule No. 2: Sibérie du sud 2: Tepsej I-III, Ust'-Tuba I-VI (Russie, Khakassie). Paris, 1995. $153 \mathrm{p}$.

$$
-565-
$$


4. Bokovenko N.A. K voprosu o datirovke nekotorykh eniseiskikh izobrazhenii vsadnikov [On the Issue of Dating Some of the Yenisei Images of Riders] // Skifo-sibirskii mir. Iskusstvo i ideologiia [Scythian-Siberian world. Art and Ideology]. Novosibirsk: Nauka, 1987. Pp. 75-80.

5. Bokovenko N.A., Leontiev N.V. Issledovanie petroglifov na iuge Krasnoiarskogo kraia [The Study of Petroglyphs in the South of the Krasnoyarsk Territory] // Arkheologicheskie otkrytiia 1983 goda [Archaeological Discoveries in 1983]. Moscow: Nauka, 1985. 192 p.

6. Cave art of the Middle Enisey. Zelenogorsk, 2007. 224 p.

7. Esin Iu.N. Problemy vydeleniia izobrazhenii afanas'evskoi kul'tury v naskal'nom iskusstve Minusinskoi kotloviny [The Problem of Determining the Images of the Afanasiev Culture in the Rock Art of the Minusinsk Hollow] // Afanasiev's Collection. Barnaul: Azbuka, 2010. Pp. 53-73.

8. Esin Iu.N. Taina bogov drevnei stepi [The Mystery of the Gods of the Ancient Steppe]. Krasnoyarsk: Khakass Research Institute of Language, Literature and History, 2010a. 184 p.

9. Francfor H.-P., Sacchi D. Archeologieet histoire de l’art: Questions de chronologie, de style etd interpretation // Arts Asiatiques. Annaies du muse'e national des Art asiatiques Guimet et du muse'e Cernuschi. Extrait, 1993. T. XLVIII. p. 29-34.

10. Kovaleva O.V. Naskal'nye risunki epokhi bronzy Minusinskoi kotloviny [Rock Drawings of the Bronze Age of the Minusinsk Hollow]. Novosibirsk: Publishing House of the Institute of Archaeology of the SB RAS, 2011. $160 \mathrm{p}$.

11. Kubarev V.D. Petroglify Kalbak-Tasha I [Petroglyphs of the Kalbak-Tash I]. Novosibirsk: Publishing House of the Institute of Archaeology and Ethnography of the SB RAS, 2011. 444 p.

12. Miklashevich E.A. Issledovanie pamiatnikov naskal'nogo iskusstva Minusinskoi kotloviny v 2012-2013 godakh [The Study of Rock Art Sites of the Minusinsk Hollow in 2012-2013] // Problemy arkheologii, etnografi, antropologii Sibiri i sopredel'nykh territorii [Problems of Archeology, Ethnography, Anthropology of Siberia and Adjacent Areas]: materials of the Final Session of the Institute of Archaeology and Ethnography of the SB RAS. Novosibirsk: Publishing House of the Institute of Archaeology and Ethnography of the SB RAS, 2013. Pp. 255-259.

13. Nikolaeva T.V. Izobrazheniia na plitakh ograd kurganov tagarskoi kul'tury (metodika $i$ khronologiia) [The Images on the Plates of the Fences of the Tagar Mounds (Technique and Chronology)]: Summary of the Author's Ph.D. Thesis in History/ T.V. Nikolaeva. Kemerovo, 1983. 20 p.

14. Pankov S.V. Tashtykskie gravirovki na Tepsee [Tashtyk Engraving on Tepsei] / Arkheologiia i etnografia Altaia [Archaeology and Ethnography of the Altai] Gorno-Altaisk, 2004. Vol. 2. Pp. 5260 .

15. Piatkin B.N., Martynov A.I. Shalabolinskiye petroglify [Shalabolinsk Petroglyphs]. Krasnoyarsk: Publishing House of the Krasnoyarsk. University, 1985. -192 p.

16. Podolsky N.L. O printsipakh datirovki naskal'nykh izobrazhenii [On the Principles of Rock Drawings Dating] // SA. 1973. No. 3. Pp. 266-275.

17. Rusakova I.D. K voprosu o khronologii drevneishikh petroglifov Minusinskoi kotloviny [On the Issue of the Chronology of the Most Ancient Petroglyphs of the Minusinsk Hollow] // Mir naskal'nogo iskusstva [The World of Rock Art]. Proceedings of the International Conference. Moscow, 2005. Pp. 214-218.

18. Savinov D.G. K voprosu o khronologii i semantike izobrazhenii na plitakh ograd tagarskikh kurganov (po materialam mogil'nikov u gory Turan) [On the Issue of Chronology and Semantics of the 
Images on the Plates of the Tagar Mounds' Fences (Based on the Data of the Burials at Mount Turan)] // Iuzhnaia Sibir' v skifo-sarmatskuiu epokhu [Southern Siberia in the Scythian-Sarmatian Period]. Proceedings of the Department of Archaeology. Kemerovo, 1976. Vol. 8. Pp. 57-73.

19. Savinov D.G. Minusinskaia provintsia Khunnu (po materialam arkheologicheskikh issledovanii 1984-1989) [Minusinskaia Province Khunnu (Based on Archaeological Research of 19841989)]. Saint Petersburg, 2009. 226 p.

20. Sher Ia. A. Petroglify Srednei i Tsentral'noi Azii [Petroglyphs of the Central Asia]. Moscow.: Nauka, 1980. 328 p.

21. Sovetova O.S. Siuzhet s velikanami na skalakh Tepseia [The Plot with the Giants on the Rocks of Tepsei] // Skifo-sibirskii mir: iskusstvo i ideologiia [Scythian-Siberian World: Art and Ideology]. Novosibirsk, 1987. Pp. 173-176.

22. Sovetova O.S., Mukhareva A.N., Abolonkova I.V. Mestonakhozhdenie Tepsei I: istoriia izucheniia i sovremennoe sostoianie [Location of Tepsei I: History of Research and the Current State] // Arkheologiia Iuzhnoy Sibiri. K 80-letiiu A. I. Martynova [Archaeology of Southern Siberia. On the 80th Anniversary of A.I. Martynov]. Kemerovo: Kuzbassvuzizdat, 2012. Vol. 26. Pp. 77-91.

23. Sovetova O.S. Petroglify gory Tepsey [Petroglyphs of Mount Tepsei] // Drevnee iskusstvo Azii. Petroglify [The Ancient Art of Asia. Petroglyphs.] Kemerovo: Kuzbassvuzizdat, 1995. Pp. 33-54.

24. Sovetova O.S., Miklashevich E.A. Khronologicheskie $i$ stilisticheskie osobennosti sredneeniseiskikh petroglifov [Chronological and Stylistic Features of the Middle Yenisei Petroglyphs] // Arkheologiia, etnografiia i muzeinoe delo [Archaeology, Ethnology and Museum Study]. Kemerovo, 1999. Pp. 47-74.

25. Spassky G.I. O dostoprimechatel'nykh pamiatnikakh sibirskikh drevnostei i o skhodstve nekotorykh iz nikh s velikorusskimi [About Noteworthy Monuments of Siberian Antiquities and the Similarity of Some of Them with the Great Russian] // Zapiski Imperatorskogo Russkogo Geograficheskogo Obshchestva [Notes of the Imperial Russian Geographical Society]. 1857. Book XII. 181 p. 


\section{О возможностях стратиграфического анализа для хронологической атрибуции \\ памятников наскального искусства \\ (на примере петроглифов Тепсея)}

И.В. Аболонкова, М.А. Талягина

Кемеровский государственный университет

Россия, 650043, Кемерово, ул. Красная, 6

Статья посвящена стратиграфическому анализу петроглифов одной из плоскостей с многочисленными палимпсестами памятника наскального искусства Тепсей. На ней представлены зооморфные и антропоморфные фигуры, выполненные техникой выбивки. В настоящее время существует масса мнений относительно датировок тех или иных рисунков этой плоскости. Использование стратиграфического метода позволило проследить последовательность нанесения изображений на плоскость, привлечение дополнительных методов - определить их относительную хронологию. В результате проведенного анализа были выявлены хронологические рамки создания петроглифов: от эпохи неолита (?) до этнографического времени. В целом полученные результаты могут быть использованы при датировании аналогичных рисунков как на Тепсее, так и на других памятниках наскального искусства сопредельных территорий.

Ключевые слова: археологический комплекс Тепсей, Тепсей II, петроглиф, стратиграфический метод, палимпсест.

Научная специальность: 07.00.00 - исторические науки. 